Assiut University web-site: www.aun.edu.eg

\title{
EFFECT OF GAMMA RAYS RADIATION ON THE BACTERIOLOGICAL QUALITY OF ICE CREAM
}

\author{
EL-DOSOKY, H.F.A. ${ }^{1}$ and SHEREEN, S. MOSTAFA ${ }^{2}$ \\ ${ }^{1}$ Food Hygiene Dept. Mansoura Provential Lab. Animal Health Research Institute \\ ${ }^{2}$ Microbiololgy Dept. Mansoura Provential Lab. Animal Health Research Institute
}

Received: 26 December 2018; Accepted: 31 January 2019

\begin{abstract}
In this study, 100 samples of ice cream which were divided into 2 groups (50 vanilla and 50 chocolate) collected individually from different supermarkets in Mansoura city, Egypt, for sensory and bacteriological examination before subjection for radiation, then each group was divided into 2 subgroups and exposed to radiation. The $1^{\text {st }}$ subgroup from the 2 groups was exposed to $2 \mathrm{KGy}$ of gamma rays and the $2^{\text {nd }}$ subgroup from the 2 groups was exposed to $3 \mathrm{KGy}$ of gamma rays. After the radiation exposure, all the subgroups were subjected to sensory and bacteriological examination to detect the counts of aerobic plate bacteria; Staph. aureus; Bacillus cereus and coliforms. For the vanilla samples before radiation, the counts were $1.8 \times 10^{4} \pm 0.14 \times 10^{2}, 0.28 \times 10^{2} \pm 0.095 \times 10^{2}$, $2.2 \times 10^{2} \pm 0.4 \times 10^{2}$ and $1.6 \times 10^{2} \pm 0.06 \times 10^{2} \mathrm{cfu} / \mathrm{ml}$ respectively, and the counts after radiation in the $1^{\text {st }}$ subgroup were $1.7 \times 10^{3} \pm 0.03 \times 10^{2}, 0.06 \times 10^{2} \pm 0.04 \times 10^{2}, 0.6 \times 10^{2} \pm 0.13 \times 10^{2}$ and $0.06 \times 10^{2} \pm 0.026 \times 10^{2} \mathrm{cfu} / \mathrm{ml}$ respectively, and in the $2^{\text {nd }}$ subgroup were $0.7 \times 10^{2} \pm 0.07 \times 10^{2}, \mathrm{ND}$ (not detected), $0.08 \times 10^{2} \pm 0.07 \times 10^{2}$ and ND $\mathrm{cfu} / \mathrm{ml}$ respectively. For the chocolate samples before radiation, the counts were $3.8 \times 10^{4} \pm 0.27 \times 10^{2} ; 0.5 \times 10^{2} \pm$ $0.03 \times 10^{2} ; 0.8 \times 10^{2} \pm 0.15 \times 10^{2}$ and $1.5 \times 10^{2} \pm 0.07 \times 10^{2} \mathrm{cfu} / \mathrm{ml}$ respectively, and the counts after radiation in the $1^{\mathrm{st}}$ subgroup were $2.4 \times 10^{3} \pm 0.04 \times 10^{2}, \mathrm{ND}, 0.13 \times 10^{2} \pm 0.025 \times 10^{2}$ and $0.04 \times 10^{2} \pm 0.017 \times 10^{2} \mathrm{cfu} / \mathrm{ml}$ respectively, and in the $2^{\text {nd }}$ subgroup were $1.6 \times 10^{2} \pm 0.026 \times 10^{2}, \mathrm{ND}, 0.04 \times 10^{2} \pm 0.01 \times 10^{2}$ and $\mathrm{ND} \mathrm{cfu} / \mathrm{ml}$ respectively. About the incidence of the isolated bacteria in the vanilla ice cream samples, E. coli, L. monocytogenes and Y. enterocolitica were before the exposure to radiation in percentages as 12,10 and $6 \%$ respectively, and in the chocolate samples were 10,8 and $2 \%$ respectively. While, after the radiation exposure, non of E. coli, $L$. monocytogenes and $Y$. enterocolitica could be isolated from both the vanilla and chocolate samples. In addition, Salmonella typhimurium could not be isolated at all. Therefore, gamma irradiation can be applied at dose of 3 $\mathrm{kGy}$ to improve the microbial quality and safety of frozen ice cream products without adverse effects on human health and their sensory acceptability.
\end{abstract}

Key words: Ice cream radiation

\section{INTRODUCTION}

Ice cream is a major dairy product of interest for large population. It is sold both in package (cups, cones and cartons); in open containers at the retail outlets, which is distributed manually in scoops, cones across counters. Due to its nutrient contents and long storage even though it is stored in a frozen state, the product can be a good source for microbial growth (Warke et al., 2000; Lee et al., 2009).

During processing of ice cream, there was a potential hazard due to addition of contaminated ingredients after the pasteurization step. Furthermore, the microbial quality of ice cream

Corresponding author: EL-DOSOKY, H.F.A.

E-mail address: rafat552008@yahoo.com

Present address: Food Hygiene Dept. Mansoura Provential Lab. Animal Health Research Institute during retail marketing may affected by the post production handling of the product as well as efficiency and sanitary conditions during frozen storage. The lack of efficient frozen storage under warm tropical climatic conditions gives a chance for temperature changes during transportation and distribution of ice cream. Under such conditions, bacteria can proliferate leading to occasional food poisoning events (Champagne et al., 1994; Kanbakna et al., 2004). Radiation process has a positive effect in reducing the microbial counts and improving the safety and shelf-stability of food products without reducing their nutritional or sensory quality (Anon, 2003).

The present study was undertaken to investigate the efficacy of low-dose irradiation on 2 different flavors (vanilla and chocolate) ice cream to improve their microbial quality and getting safety. 


\section{MATERIALS AND METHODS}

One hundred ice cream samples was collected individually from different supermarkets at Mansoura city Egypt, in the form of 2 groups $\left(1^{\text {st }}\right.$ group was 50 vanilla ice cream samples and $2^{\text {nd }}$ group was 50 chocolate ice cream samples). The samples were transferred to the laboratory in icebox and examined firstly before radiation for sensory and bacteriological examination. After that, the 2 groups were divided into 2 subgroups (each subgroup was 25 sample) The $1^{\text {st }}$ subgroup from the 2 groups was exposed to $2 \mathrm{KGy}$ of gamma rays and the $2^{\text {nd }}$ subgroup from the 2 groups was exposed to $3 \mathrm{KGy}$ of gamma rays. Each subgroup was packed in sterile polyethylene bag heat sealed then sent to the National Center for Radiation Research and Technology (NCRRT), Cairo, Egypt. The irradiation source was Cobalt 60 irradiation model ISS LEDDVATED. The dose rate was established using alanine transfer dosimeter (for measuring the dose rate) and variation in the absorption of irradiation dose was minimized by placing the samples within a uniform area of the irradiation field. After irradiation, $25 \mathrm{ml}$ of each exposed samples after thawing was homogenized with $225 \mathrm{ml}$ of $0.1 \%$ sterile peptone water in a stomacher for sample homogenization at $3000 \mathrm{rpm}$ for 2.5 minutes followed by 10 folds 6 serial dilutions in $0.1 \%$ sterile peptone water. After that, the 2 groups (in the form of 4 subgroups) were examined as the following:

1- Sensory examination: experts in sensory evaluation evaluated changes in color, appearance, odor and texture and freshness quality.

\section{2-Bacteriological examination:}

a) Aerobic plate count according to APHA (2001).

b) Staph aureus count according to FDA (2002) using Baird-Parker agar plates, that were incubated at $35^{\circ} \mathrm{C}$ for $48 \mathrm{hr}$. and the suspected Staph. aureus colonies were isolated and confirmed by catalase, coagulase, thermostable nuclease and VogesProskauer tests.

c) Bacillus cereus count according to the technique recommended by ISO 7932 (2004) d) Coliforms count according to FDA (2005) using most probable number technique (MPN).

e) E. coli isolation according to FDA (2002) using sorbitol MacConkey agar medium (Oxoid, England).

f) Salmonella isolation according to the technique recommended by ISO 6579 (2002).

g) Listeria monocytogenes isolation according to the technique recommended by USDA; FSIS (1989) and FAO (1992).

h) Yersinia enterocolitica isolation according to Schiemann (1982) using pre-enrichment culture on bile oxalate sorbose then culture on Cefuslodin Irgasan Novobiocin plate (CIN) according to Walker and Gilmour (1986).

3-Detection of virulence genes: the isolated Staph. aureus and E. coli were examined by using PCR for detection of Staph. aureus enterotoxins genes and E. coli (stx1 and stx2) genes; in which DNA extraction from the samples was performed using the QIA amp DNA Mini kit (Qiagen, Germany, GmbH) with modifications from the manufacturer's recommendations. Briefly, $200 \mu \mathrm{l}$ of the sample suspension was incubated with $10 \mu \mathrm{l}$ of proteinase $\mathrm{K}$ and $200 \mu \mathrm{l}$ of lysis buffer at $56^{\circ} \mathrm{C}$ for $10 \mathrm{~min}$. After incubation, $200 \mu \mathrm{l}$ of $100 \%$ ethanol was added to the lysate. The sample was then washed and centrifuged following the manufacturer's recommendations. Nucleic acid was eluted with $100 \mu$ l of elution buffer provided in the kit. Oligonucleotide Primers used were supplied from Metabion (Germany) were listed in Table 1. For multiplex PCR of each gene, primers were utilized in a 50- $\mu 1$ reaction containing $25 \mu 1$ of Emerald Amp Max PCR Master Mix (Takara, Japan), $1 \mu \mathrm{l}$ of each primer of $20 \mathrm{pmol}$ concentration, $8 \mu \mathrm{l}$ of water, and $7 \mu \mathrm{l}$ of DNA template. The reaction was performed in an Applied biosystem 2720 thermal cycler. Analysis of the PCR Products by electrophoresis on $1.5 \%$ agarose gel (Applichem, Germany, GmbH) in 1x TBE buffer at room temperature using gradients of $5 \mathrm{~V} / \mathrm{cm}$. For gel analysis, $30 \mu \mathrm{l}$ of the multiplex PCR products were loaded in each gel slot. Gelpilot 100 bp DNA ladder (Qiagen, Germany, $\mathrm{GmbH}$ ) was used to determine the fragment sizes. The gel was photographed by a gel documentation system (Alpha Innotech, Biometra) and the data was analyzed through computer software. 
Table 1: Primers sequences, target genes, amplicon sizes and cycling conditions for the bold genes of Staph. aureus and E. coli used in multiplex PCR.

\begin{tabular}{|c|c|c|c|c|c|c|c|c|c|}
\hline \multirow[b]{2}{*}{ organism } & \multirow{2}{*}{$\begin{array}{l}\text { Target gene } \\
\text { (enterotoxin) }\end{array}$} & \multirow{2}{*}{$\begin{array}{c}\text { Primers } \\
\text { sequences }\end{array}$} & \multirow{2}{*}{$\begin{array}{l}\text { Amplified } \\
\text { segment } \\
\text { (bp) }\end{array}$} & \multirow{2}{*}{$\begin{array}{c}\text { Primary } \\
\text { denaturation }\end{array}$} & \multicolumn{3}{|c|}{ Amplification (35 cycles) } & \multirow{2}{*}{$\begin{array}{c}\text { Final } \\
\text { extension }\end{array}$} & \multirow[b]{2}{*}{ Reference } \\
\hline & & & & & $\begin{array}{c}\text { Secondary } \\
\text { denaturation }\end{array}$ & Annealing & Extension & & \\
\hline \multirow{11}{*}{$\begin{array}{l}\text { Staph. } \\
\text { aureus }\end{array}$} & \multirow[t]{3}{*}{$\operatorname{Sea}(A)$} & GGTTATCA & \multirow[t]{3}{*}{102} & $94^{\circ} \mathrm{C}$ & $94^{\circ} \mathrm{C}$ & $50^{\circ} \mathrm{C}$ & $72^{\circ} \mathrm{C}$ & \multirow{11}{*}{$\begin{array}{c}72^{\circ} \mathrm{C} \\
10 \mathrm{~min} .\end{array}$} & \multirow{11}{*}{ 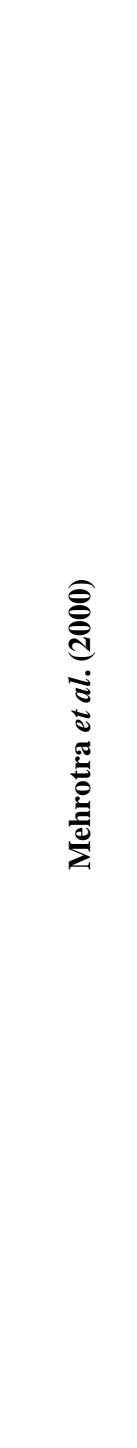 } \\
\hline & & $\begin{array}{c}\text { ATGTGCG } \\
\text { GGTGG }\end{array}$ & & $5 \mathrm{~min}$. & $30 \mathrm{sec}$. & $40 \mathrm{sec}$. & $40 \mathrm{sec}$. & & \\
\hline & & $\begin{array}{c}\text { CGGCACTT } \\
\text { TTTTCTCT } \\
\text { TCGG }\end{array}$ & & & & & & & \\
\hline & \multirow[t]{2}{*}{$\operatorname{Seb}(B)$} & $\begin{array}{c}\text { GTATGGT } \\
\text { GGTGTAA } \\
\text { CTGAGC }\end{array}$ & \multirow[t]{2}{*}{164} & & & & & & \\
\hline & & $\begin{array}{c}\text { CCAAATA } \\
\text { GTGACGA } \\
\text { GTTAGG }\end{array}$ & & & & & & & \\
\hline & \multirow[t]{2}{*}{$\operatorname{Sec}(C)$} & $\begin{array}{c}\text { AGATGAA } \\
\text { GTAGTTG } \\
\text { ATGTGTAT } \\
\text { GG }\end{array}$ & \multirow[t]{2}{*}{451} & & & & & & \\
\hline & & $\begin{array}{c}\text { CACACTTT } \\
\text { TAGAATC } \\
\text { AACCG }\end{array}$ & & & & & & & \\
\hline & \multirow[t]{2}{*}{$\operatorname{Sed}(D)$} & $\begin{array}{c}\text { CCAATAA } \\
\text { TAGGAGA } \\
\text { AAATAAA } \\
\text { AG }\end{array}$ & \multirow[t]{2}{*}{278} & & & & & & \\
\hline & & $\begin{array}{c}\text { ATTGGTAT } \\
\text { TTTTTTTC } \\
\text { GTTC }\end{array}$ & & & & & & & \\
\hline & \multirow[t]{2}{*}{$\operatorname{See}(E)$} & $\begin{array}{c}\text { AGGTTTTT } \\
\text { TCACAGG } \\
\text { TCATCC }\end{array}$ & \multirow[t]{2}{*}{209} & & & & & & \\
\hline & & $\begin{array}{c}\text { CTTTTTTT } \\
\text { TCTTCGGT } \\
\text { CAATC }\end{array}$ & & & & & & & \\
\hline \multirow[t]{5}{*}{ E. coli } & \multirow[t]{3}{*}{ stx 1} & ACACTGG & \multirow[t]{3}{*}{614} & $94^{\circ} \mathrm{C}$ & $94^{\circ} \mathrm{C}$ & $58^{\circ} \mathrm{C}$ & $72^{\circ} \mathrm{C}$ & $72^{\circ} \mathrm{C}$ & \multirow{5}{*}{ 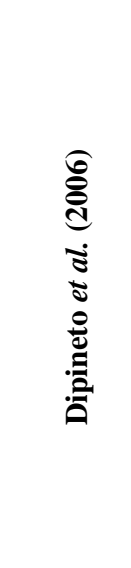 } \\
\hline & & $\begin{array}{c}\text { ATGATCTC } \\
\text { AGTGG }\end{array}$ & & $5 \mathrm{~min}$. & $30 \mathrm{sec}$. & $40 \mathrm{sec}$. & $45 \mathrm{sec}$. & $10 \mathrm{~min}$ & \\
\hline & & $\begin{array}{c}\text { CTGAATCC } \\
\text { CCCTCCAT } \\
\text { TATG }\end{array}$ & & & & & & & \\
\hline & \multirow[t]{2}{*}{ stx2 } & $\begin{array}{l}\text { CCATGAC } \\
\text { AACGGAC } \\
\text { AGCAGTT }\end{array}$ & \multirow[t]{2}{*}{779} & & & & & & \\
\hline & & $\begin{array}{c}\text { CCTGTCAA } \\
\text { CTGAG } \\
\text { CAGCACTT } \\
\text { TG }\end{array}$ & & & & & & & \\
\hline
\end{tabular}




\section{RESULTS}

Table 2: Statistical analytical results of the examined ice cream bold samples.

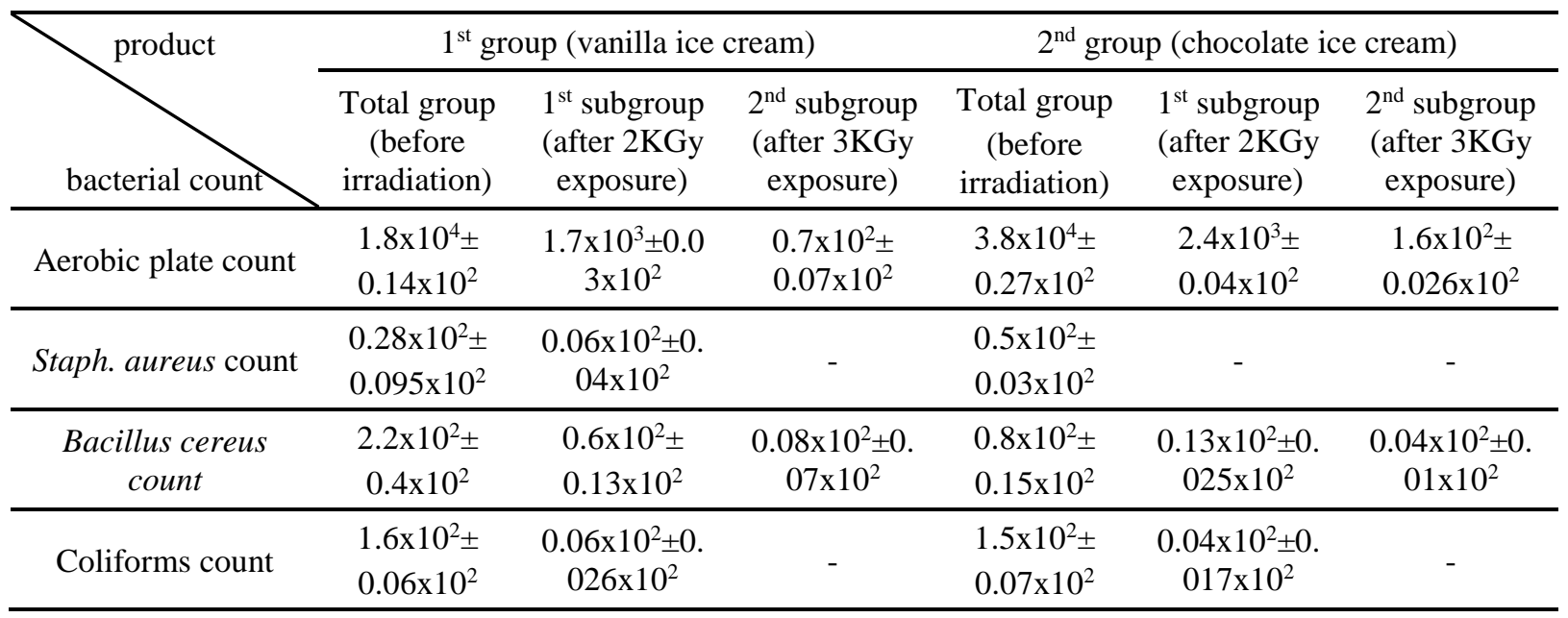

Table 3: Incidence of the isolated bacteria from the examined ice cream bold samples.

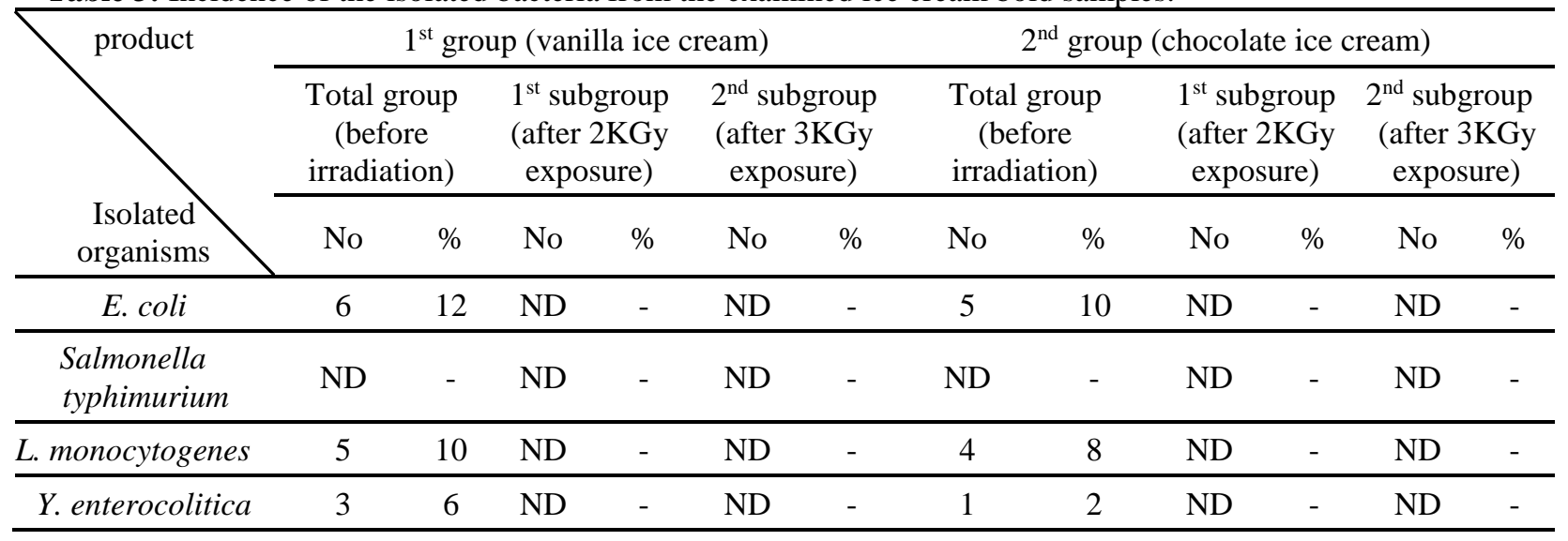

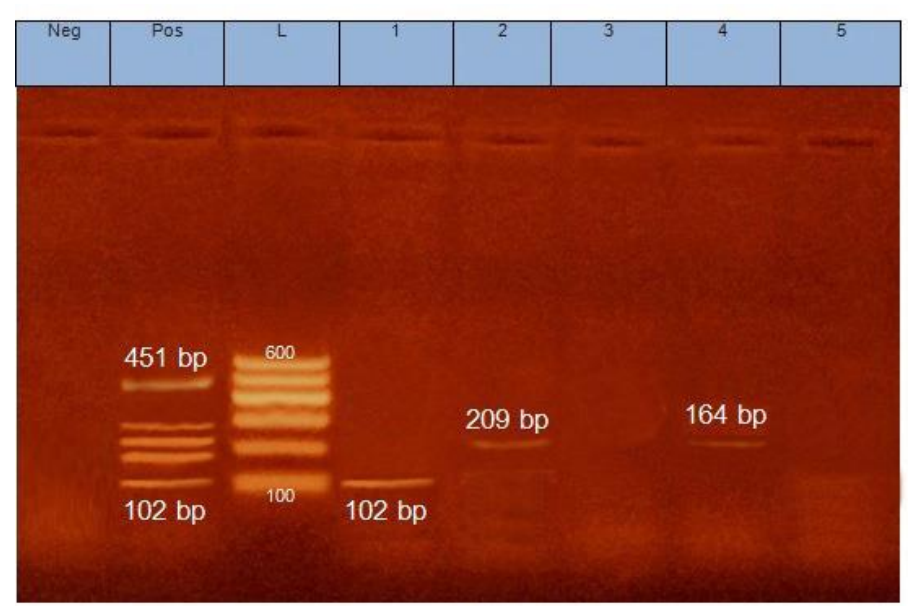

Fig. 1: Agarose gel electrophoresis of Staph. aureus PCR products using Staph. aureus enterotoxins primers for A, B, C, D and E enterotoxins

Lane Neg means negative control

Lane Pos means positive control

Lane L means 100 bp DNA ladder

Lane 1 means positive amplification of $102 \mathrm{bp}$ for enterotoxin A for a chocolate ice cream sample

Lane 2 means positive amplification of $209 \mathrm{bp}$ for enterotoxin $\mathrm{E}$ for a vanilla ice cream sample

Lane 4 means positive amplification of 164 bp for enterotoxin B for a chocolate ice cream sample

Lane 3 \& 5 means negative PCR products for vanilla and chocolate ice cream samples 


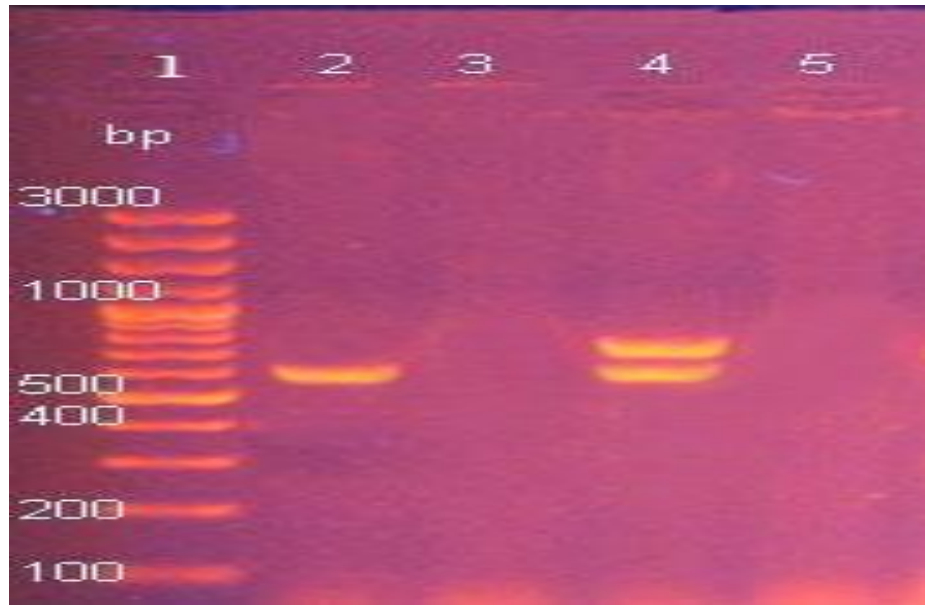

Fig. 2: Agarose gel electrophoresis of E. coli PCR products using stxl and stx2 primers Lane 1 means DNA ladder

Lane 3 \& 5 means negative PCR products for vanilla and chocolate ice cream samples

Lane 2 means positive amplification of $614 \mathrm{bp}$ for stx 1 gene in a vanilla ice cream sample

Lane 4 means positive amplification of 614 bp for stx 1 gene and $779 b p$ for stx 2 gene in a vanilla ice cream sample

\section{DISCUSSION}

Ice cream considered as a delicious and tasty food, worldwide, its processing needs many steps and different food additives that may be bacteriologically contaminated. The obtained results of aerobic plate count (APC) for the examined ice cream samples before irradiation in Table 2 were nearly achieved by Gunsen (2002) who mentioned that the mean levels of total mesophilic aerobic bacteria in unmixed, cocoa and total ice creams samples were $3.3 \times 10^{5}, 1.03 \times 10^{4}$ and $1.33 \times 10^{5} \mathrm{cfu} / \mathrm{g}$, respectively; Aslantas (2002) found the number of viable aerobic bacteria ranged from $3.4 \times 10^{3}-2.3 \times 10^{6}$ $\mathrm{cfu} / \mathrm{g}$ in the examined ice cream samples; Yucel and Ctak (2002) evaluated ice cream samples bacteriologically for total aerobic bacterial counts which were $2.5 \times 10^{2}-3.0 \times 10^{4} \mathrm{cfu} / \mathrm{ml}$. The difference in APC may be attributed to the sanitary status during processing or storage and the bacteriological state of additives. While the results of APC in Table 2 after gamma irradiation were nearly in accordance with those obtained by Kamat et al. (2001) who investigated vanilla and chocolate ice cream after exposure to $1 \mathrm{kGy}$ where the counts were reduced by one log cycle; Kim et al. (2005) indicated that irradiation at $5 \mathrm{kGy}$ or less was effective to ensure safety of ice cream and significantly reduced the level of APC; Badr (2013) showed that irradiation treatments significantly reduced the counts of microbial populations.

The achieved results of Staph. aureus count before irradiation in Table 2 \& Fig 1 declared that the enterotoxigenic strains were found in 3 samples ( 1 from vanilla ice cream and 2 from chocolate ice cream) for A, E \& B enterotoxigenic genes, the results nearly as reported by Yucel and Ctak (2002) who found Staph. aureus count $1.0 \times 10^{2}-3.0 \times 10^{3}$ $\mathrm{cfu} / \mathrm{ml}$ in the examined ice cream samples also, Guner et al. (2004) found the average count of Staph. aureus was $1.2-1.7 \times 10^{3} \mathrm{cfu} / \mathrm{g}$ of examined ice cream samples and Gücükoğlu et al. (2012) found $10 \%$ of the examined ice cream contained enterotoxigenic Staph. aureus. Meanwhile, the mean results of Staph. aureus count in Table 2 after gamma irradiation with $2 \mathrm{kGy}$ and $3 \mathrm{kGy}$ were nearly in accordance with those obtained by Kamat et al. (2001) who investigated the efficacy of low-dose irradiation to improve the microbial safety of vanilla and chocolate ice cream samples which were exposed, at $-72^{0} \mathrm{C}$ to irradiation at $1 \mathrm{kGy}$ dose were effective in reducing Staph. aureus. Badr (2013) assured that Ice cream samples which were gamma irradiated in the frozen state at dose of $3 \mathrm{kGy}$ completely inactivate the inoculated Staph. aureus. Ice cream samples that irradiated with $3 \mathrm{kGy}$ were acceptable for their sensory attributes during storage. The enterotoxigenic Staph. aureus could not be detected in the examined 4 subgroups after radiation.

The results of Bacillus cereus count before gamma irradiation in Table 2 were nearly in accordance with Abdel-Haleem (2005) who isolated Bacillus cereus from the examined ice cream samples with count ranged from $<10$ to $1.7 \times 10^{3} \mathrm{cfu} / \mathrm{g}$. The mean values of Bacillus cereus count in Table 2 after gamma irradiation with $2 \mathrm{kGy}$ and $3 \mathrm{kGy}$ were in accordance with Kamat et al. (2001) who mentioned that lowdose irradiation improve the microbial safety of vanilla and chocolate ice cream and resulted in reduction of microbial population by one log cycle.

The obtained results in Table 2 for coliforms count in the examined ice cream samples were before irradiation nearly similar to Warke et al. (2000) where they found coliforms count was $3.0 \times 10^{2}$ $5.8 \times 10^{4} \mathrm{cfu} / \mathrm{ml}$ in the examined ice cream samples. 
Presence of coliforms in the examined ice cream samples with higher count indicates poor hygienic practices during manufacturing, post processing contamination and unsatisfactory transportation. Meanwhile, coliforms in Table 2 after irradiation with $3 \mathrm{kGy}$ could not be detected in the 4 subgroups. Kim et al. (2005) mentioned that Gamma irradiation significantly reduced the level of coliforms population in ice cream. Badr (2013) mentioned that Enterobacteriaceae were completely inactivated in ice cream samples irradiated at $2 \mathrm{kGy}$.

Results in Table 3 declared that the incidence results of $E$. coli in the examined samples before irradiation were $12 \%$ and $10 \%$ in $1^{\text {st }}$ and $2^{\text {nd }}$ group of vanilla and chocolate ice cream respectively. There were 2 isolates of $E$. coli from vanilla ice cream were positive for stx1 (Fig 2). While, in chocolate ice cream the isolated $E$. coli were negative for stx 1 and stx 2 . The results after irradiation in Table 3 for the 4 subgroups declared that $E$. coli could not be detected in the examined samples.

The incidence results of Salmonella spp. in Table 3 declared that Salmonella spp. could not be detected by traditional methods or by PCR in all the examined groups and subgroups of vanilla and chocolate ice cream before and after irradiation. These results were in accordance with Warke et al. (2000); Windrantz and Arias (2001); Bostan and Akn (2002); Aslantas (2002) and Gunsen (2002) whom mentioned that Salmonella spp. was not isolated in any of the examined ice cream samples.

The incidence results of $L$. monocytogenes before irradiation in Table 3 were $10 \%$ and $8 \%$ in $1^{\text {st }}$ and $2^{\text {nd }}$ group of vanilla and chocolate ice cream respectively. These results were in accordance with Warke et al. (2000) who mentioned that L. monocytogenes was detected in only one sample of the opened examined ice cream samples; Cordano and Rocourt (2001) found L. monocytogenes in 3.5\% of the examined ice cream samples and Windrantz and Arias (2001) showed that presence of $L$. monocytogenes in ice cream samples were $12.3 \%$. While, higher results recorded by Molla et al. (2005) they stated that Listeria species were isolated from $43.5 \%$ of the examined ice cream samples and L. monocytogenes were isolated mainly from $19.6 \%$ of ice cream samples in vice with Ambily and Beena (2012) mentioned that Listeria spp. was not isolated from any of the examined samples and Marouf et al. (2014) failed to detect L. monocytogenes in all examined samples. While, after irradiation the obtained results assured that L. monocytogenes failed to be detected. the results of subgroups were in agree with Kamat et al. (2001) who investigated the efficacy of low-dose irradiation to improve the microbial safety of ice cream where vanilla and chocolate ice cream were exposed to irradiation at 1 $\mathrm{kGy}$ resulted in elimination of $L$. monocytogenes and
Badr (2013) stated that Enterobacteriaceae were completely inactivated in samples irradiated at $2 \mathrm{kGy}$. Furthermore, irradiation at $3 \mathrm{kGy}$ completely inactivate the inoculated L. monocytogenes.

Regarding the incidence results of $Y$. enterocolitica in the examined ice cream samples before irradiation were $6 \%$ and $2 \%$ for $1^{\text {st }}$ and $2^{\text {nd }}$ groups of vanilla and chocolate ice cream respectively in Table 3 . These results were in accordance with El-Prince and Hussein (2001) they could detect $Y$. enterocolitica in $1 \%$ of the examined ice cream samples and Erdogrul (2002) found that, out of 71 examined ice cream samples, 2 were $Y$. enterocolitica positive. Meanwhile, $Y$. enterocolitica could not be detected after irradiation which were nearly similar to those achieved by Kamat et al. (2001) who investigated the efficacy of low-dose irradiation to improve the microbial safety of ice cream where vanilla and chocolate ice cream were exposed to $1 \mathrm{kGy}$ resulted in reduction of microbial population and $Y$. enterocolitica was eliminated.

\section{CONCLUSION}

From the achieved results in the present study, it could be concluded that gamma irradiation can be applied at dose of $3 \mathrm{kGy}$ to improve the microbial safety of frozen ice cream products without adverse effects on their sensory acceptability.

\section{REFERENCES}

Abdel-Haleem, A.A. (2005): Incidence of Bacillus cereus in some sweetened dairy products and dairy desserts sold in Assiut City. Assiut Veterinary Medical J. 50(103): 63-69.

Ambily, R. and Beena, A.K. (2012): Bacteriological quality of ice cream marketed in Thrissur town, Kerala, India. Veterinary World. 5(12): 738-741.

Anon (2003): Radiation Processing for safe, shelfstable and ready-to-eat food. Proceedings of a Final Research Co-ordination Meeting held in Montreal, Canada, TECDOC-13372000, IAEA-, IAEA, Summary, p7.

APHA (American Public Health Association) (2001): Compendium methods for the microbiological examination of food, Wahington, DC.

Aslantas, O. (2002): Bacteriological quality of ice cream marketed in Kars. Kafkas Universitesi Veteriner Fakultesi Dergisi. 7(2): 143-147.

Badr, H.M. (2013): Improving the microbial safety of ice cream by gamma irradiation. Food and Public Health J.; 2(2): 40-49.

Bostan, K. and Akn, B. (2002): A study on the microbiological quality of industrial icecream. Turk Veterinerlik ve Hayvanclk Dergisi. 26(3): 623-629.

Champagne, C.P.; Laing, R.R.; Roy, D. and Mafu, A.A. (1994): Psychrotrophs in dairy products: 
their effects and their Control. Critical Review in Food Science and Nutrition, 34: 130.

Cordano, A.M. and Rocourt, J. (2001): Occurrence of Listeria monocytogenes in food in Chile. International J. of Food Microbiology. 70(1/2): 175-178.

Dipineto, L.; Santaniello, A.; Fontanella, M.; Lagos, K.; Fioretti, A. and Menna, L.F. (2006): Presence of Shiga toxin-producing E. coli O157:H7 in living layer hens. Letters in Applied Microbiology 43; 293-295.

El-Prince, Enas and Hussein, A.A.A. (2001): Occurrence of Enterobacteriaceae in ice cream with special reference to Salmonella species. Assiut Veterinary Medical J. 45 (89): 104-116.

Erdogrul, O.T. (2002): A study on isolation, identification and potential pathogenicity of Yersinia enterocolitica in plain ice cream. Milchwissenschaft, 57(3): 147-149.

FAO (1992): Manual of food quality control. J. Microbiological Analysis of Food and Agriculture Organization of the United Nations, Rome. 4 Rev. Chapter11, 119 - 129.

FDA (Food and Drug Administration) (2002): Bacteriological Analytical Manual $9^{\text {th }}$ ed. AOAC, International Arlington, VA, USA.

FDA (Food and Drug Administration) (2005): Staph. aureus, BadBugBook, Foodborne pathogenic Microorganisms and natural toxins Handbook (1992/updated 2005), USFDA/FDA, Center for food safety \& Applied nutrition.

Gücükoğlu, A.; Kevenk, T. O.; Uyanik, T.; Cadirci, O.; Terzi, G. and Alisarli, M. (2012): Detection of enterotoxigenic Staph. aureus in raw milk and dairy products by multiplex PCR. J. of Food Science. 77(11): 620-623.

Guner, A.; Ardc, M. and Keles, A. (2004): Microbiological quality of ice creams sold at pastry shops in Konya. Veteriner Bilimleri Dergisi. 20(2): 59-64.

Gunsen, U. (2002): The hygienic qualities of ice creams consumed in the centre of Bursa. Pendik Veteriner Mikrobiyoloji Dergisi. 32(1/2): 31-36.

ISO 6579 (2002): Microbiology of Food and Animal Feeding Stuffs-Horizontal Method for the Detection of Salmonella spp. ISO 7932, Geneva, Switzerland.

ISO 7932 (2004): The International Organization for Standardization 2004a Horizontal method for the enumeration of presumptive Bacillus cereus-colony count technique at $30^{\circ} \mathrm{c}$. ISO 7932, Geneva, Switzerland.

Kamat, A.; Warke, R.; Kamat, M. and Thomas, P. (2001): Low-dose irradiation as a measure to improve microbial quality of ice cream. International $\mathrm{J}$. of Food Microbiology. 62(1/2): 27-35
Kanbakna, J.; Con, A.N. and Ayor, A. (2004): Determination of microbiological contamination sources during ice cream production in Denizli, Turkey. Food Control, 15: 463-470.

Kim, H.J.; Cheorun, Jo.; Kim, D.S.; Yook, H.S. and Byun, M.W. (2005): Microbiological Contamination of Ice Cream Commercially Available in Korea and its Irradiation Effect. J. Anim. Sci. \& Technol. 47(5) 867-876.

Lee, J.W.; Kim, H.J.; Yoon, Y.; Kim, J.H.; Ham, J.S.; Byun, M.W.; Baek, M.; Jo, C. and Shin, M.G. (2009): Manufacture of ice cream with improved microbiological safety by using gamma irradiation. Radiation Physics and Chemistry, 78: 593-595.

Marouf, H.A.; Dorra, E.H. and Abo-Samra, R.G. (2014): Microbiological quality of ice cream sold in Ras El-Bar City, Damietta Governorate. Global. J. of Agriculture and Food Safety Sciences. 1: 51-65.

Mehrotra, M.; Wang, G. and Johnson, M.W. (2000): Multiplex PCR for detection of genes for Staph. aureus enterotoxin, exfoliative toxins, toxic shock syndrome toxin 1, and Methicillin resistance. J. of Clinical Microbiology, 38: 1032-1035.

Molla, B.; Yilma, R. and Alemayehu, D. (2005): Listeria monocytogenes and other Listeria species in retail meat and milk products in Addis Ababa, Ethiopia. Ethiopian J. of Health Development. 18(3):208-212.

Schiemann, D.A. (1982): Development of a two step enrichment procedure for recovery of Yersinia enterocolitica from food. Applied and environmental Microbiology, 43; 14-27.

USDA; FSIS (United State Department of Agriculture; Food Safety Inspection Service) (1989): Method for the isolation and identification of L. monocytogenes from meat and poultry products. Laboratory Communities, No. 57, US Department of Agriculture, Washington, D.C.

Walker, S.J. and Gilmour, A. (1986): The incidence of Yersinia enterocolitica like organisms in raw and pasteurized milk in Northern Ireland. J. of Applied Bacteriology. 61; 133-138.

Warke, R.; Kamat, A.; Madhusudan Kamat and Thomas, P. (2000): Incidence of pathogenic psychrotrophs in ice creams sold in some retail outlets in Mumbai, India. Food Control. 11(2): 77-83.

Windrantz, P. and Arias, M.L. (2001): Evaluation of the bacteriological quality of ice cream sold at San Jose, Costa Rica. Archivos Latinoamericanos de Nutricion. 50(3): 301303

Yucel, N. and Ctak, S. (2002): A study on existence of some microorganisms in ice-cream samples. Turk Hijyen ve Deneysel Biyoloji Dergisi. 57(3): 165-169. 


\section{تأثثير إشعاع أشعة جامـا على الجودة البكتريولوجية للآيس كريم

\author{
حاتم فتحى أحد اللسوقي ، شيرين سامي مصطفى
}

Email: rafat552008@yahoo.com Assiut University web-site: www.aun.edu.eg

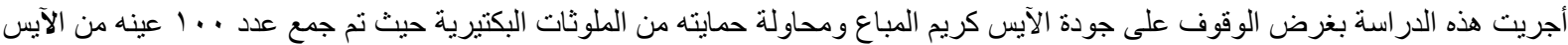

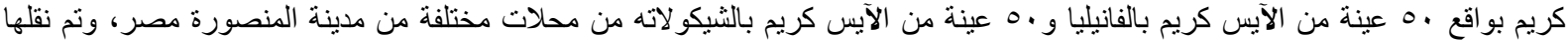

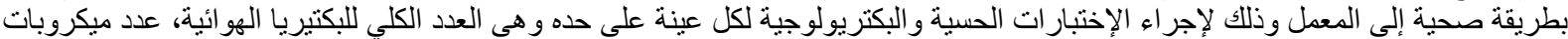

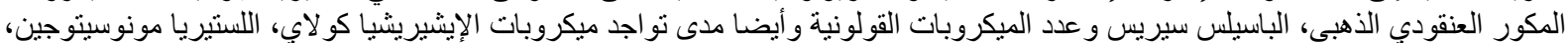

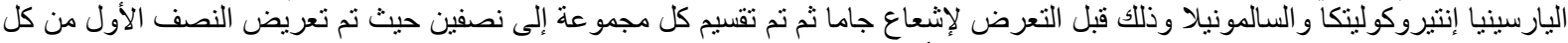

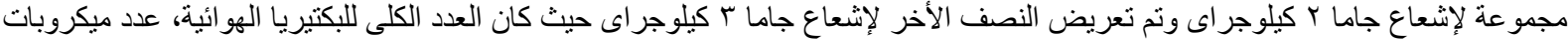

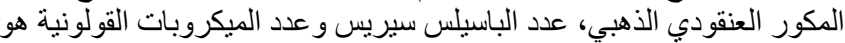
$1.8 \times 10^{4} \pm 0.14 \times 10^{2}, 0.28 \times 10^{2} \pm 0.095 \times 10^{2}, 2.2 \times 10^{2} \pm 0.4 \times 10^{2}$ and $1.6 \times 10^{2} \pm 0.06 \times 10^{2} \mathrm{cfu} / \mathrm{ml}$

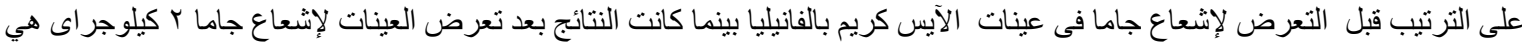
$1.7 \times 10^{3} \pm 0.03 \times 10^{2}, 0.06 \times 10^{2} \pm 0.04 \times 10^{2}, 0.6 \times 10^{2} \pm 0.13 \times 10^{2}$ and $0.06 \times 10^{2} \pm 0.026 \times 10^{2} \mathrm{cfu} / \mathrm{ml}$

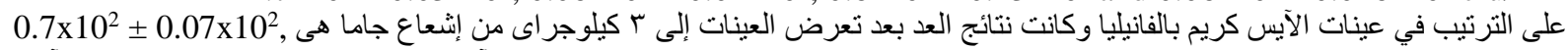
ND (not detected), 0.08x10² \pm 0.07x10²and ND cfu/ml كريم بالثيكو لاته هو

$3.8 \times 10^{4} \pm 0.27 \times 10^{2} ; 0.5 \times 10^{2} \pm 0.03 \times 10^{2} ; 0.8 \times 10^{2} \pm 0.15 \times 10^{2}$ and $1.5 \times 10^{2} \pm 0.07 \times 10^{2} \mathrm{cfu} / \mathrm{ml}$ وكانت النتائج بعد تعرض العينات لإشعاع جاما ب كيلوجر ای هي $2.4 \times 10^{3} \pm 0.04 \times 10^{2}$, ND, $0.13 \times 10^{2} \pm 0.025 \times 10^{2}$ and $0.04 \times 10^{2} \pm 0.017 \times 10^{2} \mathrm{cfu} / \mathrm{ml}$ وكانت نتائج العد بعد تعرض العينات إلى ب كيلوجر ایى من إشعاع جاما هي

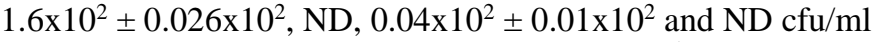

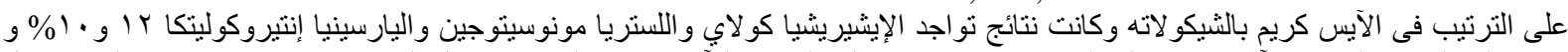

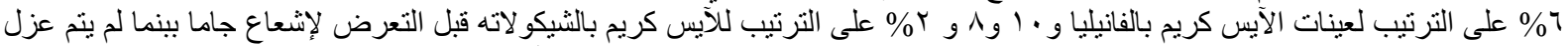

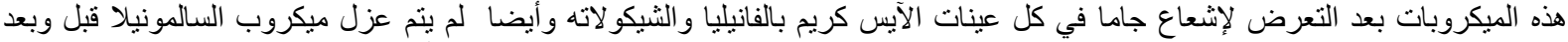
التعرض لإشعاع جاما ومما سبق يتضح مدى تاثير إشعاع جاما على البكتيريا وعدم تاثر الصفات التهات الحسية للآيس كريم بها. 